\title{
Biochemical characteristics of plant pathogenic Klebsiella pneumoniae causing root bark necrosis and wilt in pomegranate
}

\begin{abstract}
A plant pathogenic Klebsiella pneumoniae causing root bark necrosis and wilt in pomegranate was designated as Klebsiella pneumoniae strain Borkar by NCBI (accession number: KY941097.1) on the basis of 16s rRNA partial gene sequence submitted. This strain was studied for its biochemical characteristics as it was a new bacterial pathogen causing plant disease and its biochemical characteristics was compared with the known biochemical characteristics of other Klebsiella pneumoniae sub species and Klebsiella species.
\end{abstract}

The bacterium was positive for ONPG, lysine utilization, urease, vogus paskeur reaction, methyl red test, PYR, esculin hydrolysis, sorbitol, trehalose, malabiose, salicin, mannose, sucrose, glucose utilization, malonate, arabinose, rhamnose and mannitol utilization tests; whereas it was negative for ornithine utilization, Indole, $\beta$-glucoronidase, $\alpha$-galactosidase, $\beta$-xylosidase, cellobiose, maltose, Raffinose, Lactose, $\mathrm{H}_{2} \mathrm{~S}$ and Adonitol.

The plant pathogenic Klebsiella pneumoniae strain Borkar differed from Klebsiella pneumoniae in respect of sugar utilization. The plant pathogenic Klebsiella pneumoniae does not utilize $\alpha$-galactosidase, $\beta$-xylosidase, cellobiose, maltose, Raffinose, Lactose whereas Klebsiella pneumoniae utilizes these sugars.

Similarly Plant pathogenic Klebsiella pneumoniae strain Borkar differed from Klebsiella oxycota, Klebsiella pneumoniae subsp. pneumoniae, Klebsiella rhizoscleronatis, Klebsiella ozaenae and Klebsiella terigena in one or the other known biochemical characteristics.

This opportunistic soil borne bacteria has emerged as a new soil borne plant pathogen particularly on pomegranate crop. Barring one example of its infection on maize this bacterial species is new one to cause infection in the plant. The genus Klebsiella is not yet included as a genus of plant pathogenic bacteria. Therefore we propose to include the genus Klebsiella as a plant pathogen and its biochemical characteristics are described in this paper.

Keywords: biochemical tests, klebsiella sp, plant pathogenic klebsiella pneumoniae, pomegranate pathogen
Special Issue - 2018

\author{
Ajayasree TS, Borkar SG \\ Department of Plant Pathology and Agricultural microbiology, \\ Mahatma Phule Agricultural University, India
}

\section{Correspondence: Ajayasree TS, Department of Plant Pathology and Agricultural Microbiology, Mahatma Phule Agricultural University, Rahuri-4 I3722, Dist-Ahmednagar (MS),} India, Email ajayasreeI28@gmail.com

Received: June 08, 2018 | Published: July 25, 2018

\section{Introduction}

Biochemical characterization is an important tool to differentiate the bacterial genus into species and subspecies. ${ }^{1}$ The individual bacterial species and subspecies are specific in the utilization or non-utilization of particular chemical molecules. Klebsiella pneumoniae is generally a serious human pathogen causing respiratory tract infection, loss of breathing leading to pneumonia and death of patient. ${ }^{2}$ This bacterial pathogen is also known to cause infection in animals particularly in dogs and pre-weaned pigs $^{3-6}$ and in birds also. ${ }^{7-9}$ Immuno deficient animals, especially those with severe immune-deficiencies or defect in immune system, develop clinical disease symptoms associated with Klebsiella infection.

In 2016 the bacterium Klebsiella pneumoniae was reported to infect maize plant in China causing bacterial top rot disease of maize in Yunnan province. ${ }^{10}$ In subsequent year, its involvement as plant pathogen causing root bark necrosis and wilt in pomegranate was detected in pomegranate orchard of Mahatma Phule Agricultural University, Rahuri, India. ${ }^{11}$ The differentiation system of plant pathogenic Klebsiella pneumoniae species from other Klebsiella pneumoniae subspp is not available in the literature, since Klebsiella pneumoniae is recently reported as a plant pathogen. It is very necessary to characterize this plant pathogenic Klebsiella pneumoniae from other Klebsiella pneumoniae subspp and species. As the differentiation of species and subspp is generally based on biochemical tests, these were used to characterize the plant pathogenic Klebsiella pneumoniae strain Borkar, so as to differentiate it from the other known Klebsiella pneumoniae and Klebsiella species.

\section{Materials and methods}

\section{Biochemical characterization of plant pathogenic Klebsiella pneumoniae strain borkar}

Rapid biochemical identification test kits of Himedia viz. KB002 (HiAssorted $^{\mathrm{TM}}$ ), KB001 (Hi/MViC $\left.{ }^{\mathrm{TM}}\right), \mathrm{KB} 003$ (Hi25 $5^{\mathrm{TM}}$ ) and KB016 $\left(\mathrm{Hi} 24^{\mathrm{TM}}\right)$ were used for biochemical characterization of Klebsiella pneumoniae strain Borkar.

A total 35 biochemical tests included in these identification test kit were used. These tests were ONPG, lysine utilization, ornithine utilization, urease, phenyl alanine deamination, Voges proskauer, 
Methyl red, indole, PVR, $\beta$-glucoronidase, $\alpha$-galactosidase, $\beta$-xylosidase, esculin hydrolysis, sucrose, sorbitol, trehalose, glucose, cellobiose, melibiose, salicin, mannose, raffinose, lactose, TDA, nitrate reduction, $\mathrm{H}_{2} \mathrm{~S}$, citrate utilization, malonate, arabinose, xylose, adonitol, rhamnose, saccharose and mannitol. Each biochemical test kit is a standardized colorimetric identification system utilizing conventional biochemical test and carbohydrate utilization tests. The tests are based on the principle of $\mathrm{pH}$ change and substrate utilization. On inoculation with the bacterial culture in test kit media and incubation, the test media undergoes changes, due to metabolic activity of bacteria, which are indicated by a colour change in the media that are interpreted visually or after addition of the respective test reagent after incubation period.

The test kit was opened aseptically by peeling off the sealing tape. Each well of the test kit was inoculated with a loop of 24hour old bacterial culture by stab inoculation method and covered with peel off sealing tape. The kits were incubated at $35-37^{\circ} \mathrm{C}$ temperature for 24hours. The results were interpreted as per the standards given in the result interpretation chart. Addition of reagents wherever necessary was done to obtain the test results after the incubation period. The results are presented in the tabular form.

\section{Results}

Metabolic activity and utilization of different substrates by plant pathogenic Klebsiella pneumoniae strain Borkar

The bacterium was positive for ONPG, lysine utilization, urease, vogus paskeur reaction, methyl red test, PYR, esculin hydrolysis, nitrate reduction, citrate utilization and utilization of sucrose, sorbitol, trehalose, malatiose, salicin, mannose, glucose, malonate, arabinose, rhamnose and manitol as carbohydrate sugar, while it was negative for ornithine utilization, indole, $\mathrm{H}_{2} \mathrm{~S}, \beta$-glucoronidase, $\alpha$-galactosidase, and $\beta$-xylosidase and did not utilize cellobiose, maltose, raffinose, lactose and adonitol as carbohydrate sugar (Table 1). This plant pathogenic Klebsiella pneumoniae strain Borkar was different in some of the biochemical characters to other Klebsiella pneumoniae and its subspecies (Table 2A-2f).

Table I Metabolic activity and utilization of different substrates by plant pathogenic Klebsiell pneumoniae strain Borkar

\begin{tabular}{lll}
\hline $\begin{array}{l}\text { Sr. } \\
\text { No. }\end{array}$ & $\begin{array}{l}\text { Metabolic activity/ utilization of } \\
\text { substrate }\end{array}$ & $\begin{array}{l}\text { Reaction of Klebsiella } \\
\text { pneumoniae } \text { strain Borkar }\end{array}$ \\
\hline 1 & ONPG & + \\
2 & Lysine utilization & + \\
3 & Ornithine utilization & + \\
4 & Urease & V/- \\
5 & Phenyl alanine deamination & + \\
6 & VP & + \\
7 & MR & - \\
8 & Indole & + \\
9 & PYR & - \\
10 & $\beta$-glucoronidase & - \\
11 & $\alpha$-galactosidase & - \\
\hline 12 & $\beta$-xylosidase & \\
\hline
\end{tabular}

\begin{tabular}{lll}
\hline $\begin{array}{l}\text { Sr. } \\
\text { No. }\end{array}$ & Metabolic activity/ utilization of & $\begin{array}{l}\text { Reaction of Klebsiella } \\
\text { sneumoniae } \text { strain Borkar }\end{array}$ \\
\hline 13 & Esculin hydrolysis & + \\
14 & Sucrose & + \\
15 & Sorbitol & + \\
16 & Trehalose & + \\
17 & Glucose & - \\
18 & Cellobiose & + \\
19 & Melibiose & + \\
20 & Salicin & + \\
21 & Mannose & - \\
22 & Maltose & - \\
23 & Raffinose & - \\
24 & Lactose & + \\
25 & Nitrate reduction & - \\
26 & H & + \\
27 & Citrate utilization & + \\
28 & Malonate & + \\
29 & Arabinose & + \\
30 & Adanitol & + \\
31 & Rhamnose & + \\
32 & Mannitol & + \\
\hline & & + \\
\hline
\end{tabular}

$+=$ Positive, $\mathrm{V}=1 \mathrm{I}-89 \%$ positive, - = negative

Table 2 Variable characteristics of Klebsiella pneumoniae strain Borkar with comparison to other Klebsiella species

a. Variation in biochemical characteristics of Klebsiella pneumoniae strain Borkar with Klebsiella pneumoniae

\begin{tabular}{llll}
\hline Sr. No. & $\begin{array}{l}\text { Metabolic activity/ } \\
\text { utilization of substrate }\end{array}$ & $\begin{array}{l}\text { Klebsiella } \\
\text { pneumoniae }\end{array}$ & $\begin{array}{l}\text { Klebsiella } \\
\text { pneumoniae } \\
\text { strain borkar }\end{array}$ \\
\hline 1 & MR & $\mathrm{V}$ & + \\
2 & Maltose & + & - \\
3 & Raffinose & + & - \\
4 & Lactose & + & - \\
\hline
\end{tabular}

b. Variation in biochemical characteristics of Klebsiella pneumoniae strain Borkar with Klebsiella oxycota

\begin{tabular}{llll}
\hline Sr No. & $\begin{array}{l}\text { Metabolic activity/ } \\
\text { utilization of } \\
\text { substrate }\end{array}$ & $\begin{array}{l}\text { Klebsiella } \\
\text { oxycota }\end{array}$ & $\begin{array}{l}\text { Klebsiella } \\
\text { pneumoniae } \\
\text { strain Borkar }\end{array}$ \\
\hline 1 & Indole & + & - \\
2 & $\alpha$-galactosidase & + & - \\
3 & $\beta$-Xylosidase & + & - \\
4 & Cellobiose & + & - \\
5 & Maltose & + & - \\
6 & Raffinose & + & - \\
7 & Lactose & + & - \\
8 & Adonitol & + & - \\
\hline
\end{tabular}


c. Variation in biochemical characteristics of Klebsiella pneumoniae strain Borkar with Klebsiella ozaenae

\begin{tabular}{llll}
\hline Sr. No. & $\begin{array}{l}\text { Metabolic activity/ } \\
\text { utilization of } \\
\text { substrate }\end{array}$ & $\begin{array}{l}\text { Klebsiella } \\
\text { ozaenae }\end{array}$ & $\begin{array}{l}\text { Klebsiella } \\
\text { pneumoniae } \\
\text { strain Borkar }\end{array}$ \\
\hline 1 & Lysine utilization & $\mathrm{V} /-$ & + \\
2 & Urease & - & + \\
3 & VP & - & + \\
4 & $\alpha$-galactosidase & + & - \\
5 & B-Xylosidase & $\mathrm{V}$ & + \\
6 & Sucrose & - & + \\
7 & Sorbitol & $\mathrm{V}$ & - \\
8 & Cellobiose & + & - \\
9 & Maltose & + & - \\
10 & Lactose & $\mathrm{V}$ & + \\
11 & Nitrate reduction & $\mathrm{V}$ & - \\
12 & Citrate utilization & $\mathrm{V}$ & + \\
13 & Adonitol & + & \\
\hline
\end{tabular}

d. Variation in biochemical characteristics of Klebsiella pneumoniae strain Borkar with Klebsiella pneumoniae subsp. pneumoniae

\begin{tabular}{llll}
\hline Sr. No. & $\begin{array}{l}\text { Metabolic activity/ } \\
\text { utilization of substrate }\end{array}$ & $\begin{array}{l}\text { Klebsiella } \\
\text { pneumoniae } \\
\text { subsp. } \\
\text { pneumoniae }\end{array}$ & $\begin{array}{l}\text { Klebsiella } \\
\text { pneumoniae } \\
\text { strain Borkar }\end{array}$ \\
\hline 1 & MR & V & + \\
2 & $\alpha$-galactosidase & + & - \\
3 & k-Xylosidase & + & - \\
4 & Cellobiose & + & - \\
5 & Maltose & + & - \\
6 & Raffinose & + & - \\
7 & Lactose & + & - \\
8 & Adonitol & + & - \\
\hline
\end{tabular}

e. Variation in biochemical characteristics of Klebsiella pneumoniae strain Borkar with Klebsiella rhizoscleronatis

\begin{tabular}{llll}
\hline Sr. No. & $\begin{array}{l}\text { Metabolic activity/ } \\
\text { utilization of substrate }\end{array}$ & $\begin{array}{l}\text { Klebsiella } \\
\text { rhizoscleronatis }\end{array}$ & $\begin{array}{l}\text { Klebsiella } \\
\text { pneumoniae } \\
\text { strain Borkar }\end{array}$ \\
\hline 1 & ONPG & - & + \\
2 & Lysine utilization & - & + \\
3 & Urease & - & + \\
4 & VP & - & + \\
5 & $\beta-$ Xylosidase & V & - \\
6 & Esculin hydrolysis & V & + \\
7 & Sucrose & V & + \\
8 & Cellobiose & + V & - \\
9 & Maltose & + & - \\
10 & Raffinose & + & - \\
11 & Citrate utilization & - & + \\
12 & Adonitol & + & - \\
\hline
\end{tabular}

f. Variation in biochemical characteristics of Klebsiella pneumoniae strain Borkar with Klebsiella terigena

\begin{tabular}{llll}
\hline Sr. No. & $\begin{array}{l}\text { Metabolic activity/ } \\
\text { utilization of substrate }\end{array}$ & $\begin{array}{l}\text { Klebsiella } \\
\text { terigena }\end{array}$ & $\begin{array}{l}\text { Klebsiella } \\
\text { pneumoniae } \\
\text { strain Borkar }\end{array}$ \\
\hline 1 & Ornithine utilization & $\mathrm{V}$ & - \\
2 & Urease & - & + \\
3 & MR & $\mathrm{V}$ & + \\
4 & Raffinose & + & - \\
5 & Lactose & + & - \\
\hline
\end{tabular}

\section{Discussion}

The biochemical characteristics in bacteria are an important tool in their identification. Klebsiella pneumoniae, is a known important human pathogen causing pneumonia, nosocomical infection, urinary tract infection and infection of respiratory tract ${ }^{2}$ and fatal to human being. ${ }^{12}$ Klebsiella pneumoniae infection is also reported in animals and birds leading to severe enteritis, septicaemia and death. ${ }^{3,7}$ The strain of Klebsiella pneumoniae is also reported to infect maize plant in Yunnan province, $\mathrm{China}^{10}$ and recently in India on pomegranate crop causing wilt. ${ }^{11}$ The known biochemical characteristics of Klebsiella pneumoniae subspp and Klebsiella species was compared with plant pathogenic Klebsiella pneumoniae strain Borkar for its biochemical characteristics.

The plant pathogenic Klebsiella pneumoniae strain Borkar was positive for ONPG, lysine utilization, urease, VP, MR, PYR, esculin hydrolysis, nitrate reduction, citrate utilization and utilization of sucrose, sorbitol, trehalose, malatiose, salicin, mannose, glucose, malonate, arabinose, rhamnose and manitol as carbohydrate sources, while it was negative for ornithine utilization, Indole, $\mathrm{H}_{2} \mathrm{~S}$, $\beta$-glucoronidase, $\alpha$-galactocidase, $\beta$-xylosidase and did not utilize cellobiose, maltose, raffinose, lactose and adonitol.

Plant pathogenic Klebsiella pneumoniae strain Borkar was different from previously reported Klebsiella pneumoniae in utilization of at least three sugars viz, maltose, raffinose and lactose. Plant pathogenic Klebsiella pneumoniae strain Borkar did not utilized these sugars whereas Klebsiella pneumoniae utilizes these.

Klebsiella pneumoniae is also reported to be associated with plant root system, probably as nitrogen fixer in maize, poa and wheat, ${ }^{13,14}$ but not yet reported as soil borne plant pathogen. Though Huang et al. ${ }^{10}$ reported Klebsiella pneumoniae causing bacterial top rot disease of maize; it was not described as soil borne plant pathogen. Klebsiella pneumoniae strain Borkar, is a soil borne plant pathogen infecting pomegranate plant by causing root bark necrosis and wilt in the plant. This pathogen under our experimentation did not infect the maize plant causing top rot and therefore, seems to be different strain of Klebsiella pneumoniae reported from China. Thus plant pathogenic Klebsiella pneumoniae strain Borkar is different Klebsiella species and not reported earlier. The biochemical characteristics of this strain certainly differentiate it from other Klebsiella pneumoniae sub spp.

\section{Conclusion}

Plant pathogenic Klebsiella pneumoniae strain Borkar can be differentiated from other known Klebsiella pneumoniae species on the basis of various biochemical tests. This opportunistic soil borne bacteria has emerged as a new soil borne plant pathogen particularly 
on pomegranate crop. Barring one example of its infection on maize this bacterial species is new one to cause infection in the plant. The genus Klebsiella is not yet included as a genus of plant pathogenic bacteria. Therefore we propose to include the genus Klebsiella as a plant pathogen and its biochemical characteristics are described in this paper.

\section{Acknowledgements}

None.

\section{Conflict of interest}

The author declares that there is no conflict of interest

\section{References}

1. Bergey DH, Buchanan RE, Gibbons NE, et al. Bergey's manual of determinative bacteriology. Baltimore: Williams \& Wilkins; 1974.

2. Podschun R, Ullmann U. Klebsiella spp. as nosocomical pathogens: epidemiology, taxonomy, typing methods and pathogenicity factor. Clin Microbiol Rev. 1998;11(4):589-603.

3. Roberts DE, McClain HM, Hansen DS, et al. An outbreak of Klebsiella pneumoniae infection in dogs with severe enteritis and septicaemia. $J$ Vet Diagn Invest. 2000;12(2):168-173.

4. Thea B, Densie N, Andrew B. The laboratory rabbits, Guinea pigs Hamster and other rodents. USA: Academic Press; 2012. p. 637-683.

5. http://apha.defra.gov.uk/vet-gateway/surveillance/seg/pig.htm

6. Wohlwend N, Endimiani A, Francey T, et al. Third generation cephalosporin resistant Klebsiella pneumoniae isolates from humans and companion animals in Switzerland: spread of a DHA producing sequence type 11 clone in a veterinary setting. Antimicrob Agents Chemother. 2015;59(5):2949-2955.
7. Gerlach H. Bacteria. In: Ritchie BW, Harrlson GJ, Harrlson LR, editors. Avian medicines: Principles and application. Lake worth, USA: Wingers publishing; 1994. p. 949-983.

8. Dashe YG, Kazeem HM, Abdu PA, et al. Klebsiella pneumonia isolates from birds affected by natural outbreak of highly pathogenic avian influenza (H5N1) in Nigeria. Sokoto Journal of Veterinary Science. 2008;7(2):59-61.

9. Razmyar J, Zamani AH. An outbreak of yolk sac infection and deadin-shell mortality in common canary caused by Klebsiella pneumoniae. Iran J Vet Res. 2016;17(2):141-143.

10. Huang M, Li L, Yi-Xin W, et al. Pathogenicity of Klebsiella pneumonia $\left(\mathrm{KpC}_{4}\right)$ infecting maize and mice. Journal of Integrative Agriculture. 2016;15(7):1510-1520.

11. Ajayasree TS, Borkar SG, Yumlembam RA. Root barks necrosis and wilt of pomegranate: A disease of new etiology. National symposium on diagnosis and management of plant diseases: Integrated approaches and recent trends, January 9-11. Indian phytopathological society held at ICAR Research complex for NEH region. Umium, Meghalaya, India; 2017. p. 98

12. Sugiyama H, Ono Y. Klebsiella pneumoniae pneumonia. Ryoikibetsu shokogun shirizu. 1999;23:366-368.

13. Chelius MK, Triplett EW. Immunolocalization of dinitrogenase reductase produced by Klebsiella pneumoniae in-association with Zea mays. Appl Environ Microbiol. 2000;66(2):783-787.

14. Haahtela K, Kari K. The role of root associated Klebsiella pneumoniae in the nitrogen nutrition of poa pratensis and Triticum aestivum as estimated by the method of $15 \mathrm{~N}$ isotope dilution. Plant soil. $1986 ; 90(1-3): 245-254$ 